Sains Malaysiana 50(5)(2021): 1343-1356

http://doi.org/10.17576/jsm-2021-5005-14

\title{
Effect of Food Colorants Supplementation on Reactive Oxygen Species, Antioxidant Vitamins Level and DNA Damage
}

(Kesan Tambahan Pewarna Makanan pada Spesies Oksigen Reaktif, Tahap Antioksidan Vitamin dan Kerosakan DNA)

\author{
SADAF SHAKOOR*, Amin IsMaIL, ZIA-UR-RAHMAN, MOHD REDZWAN SABRAN \& NORHAFIZAH MOHTARRUdiN
}

\begin{abstract}
There are various undesirable products generated from endogenous aerobic metabolism such as reactive oxygen species (ROS). Physiological and biochemical lesions are caused by ROS and which give rise to oxidative damages towards DNA, proteins and lipids which ultimately lead to cell death. This study was aimed to examine the effect of oral administration of food colorants (tartrazine and curcumin) on the oxidants and antioxidants level in blood and fecal of rats after 15, 30, and 45 days. Two doses were used based on the admissible daily intake (ADI) of 9.6 and 96 (high) $\mathrm{mg} / \mathrm{kg} / \mathrm{body}$ weight for tartrazine, 3.85 and $38.56 \mathrm{mg} / \mathrm{kg} / \mathrm{body}$ weight for curcumin. The results showed that oral administration of tartrazine had significantly increased the total oxidant level, arylesterase, glutathione reductase, and MDA whereas there was significantly decreased the total antioxidants level, catalase, glutathione peroxidase in plasma and fecal after 30 and 45 days. Vitamin $E$ and $C$ were decreased in plasma. Fecal showed high level of vitamin $A$. High dose of tartrazine caused alteration in the aldehyde reactive probe (ARP) sites of DNA showing the DNA damage. After 45 day, significant increment was observed in the level of AST in low and high curcumin treated group. Whereas, elevations of arylestrase were seen in high curcumin group after 45 day. High dose of curcumin significantly $(P \leq 0.05)$ decreased the concentration of vitamin $C$ after 45 days of treatment and increased the level of vitamin $E$ in plasma of treated groups after 30 and 45 days of treatment. The present study showed that the ADI and doses up to 10 times higher than ADI showed negative effects on antioxidant level and demonstrated the importance of using appropriate doses of food colorants such as tartrazine and curcumin in different processed food products.
\end{abstract}

Keywords: Antioxidants; arylesterase; food colorants; glutathione; lipid peroxidation; ROS

\section{ABSTRAK}

Terdapat pelbagai produk yang tidak diingini yang dijanakan daripada metabolisme aerobik endogen seperti spesies oksigen reaktif (ROS). Lesi fisiologikal dan biokimia disebabkan oleh ROS yang mengakibatkan peningkatan kepada kerosakan oksidatif terhadap DNA, protein dan lipid yang akhirnya membawa kepada kematian sel. Kajian ini bertujuan untuk meneliti kesan pelaksanaan oral pewarna makanan (tartrazin dan kurkumin) ke atas tahap oksidan dan antioksidan dalam darah dan najis tikus selepas 15, 30 dan 45 hari. Dua dos telah digunakan berdasarkan pengambilan harian yang dibenarkan (ADI) iaitu 9.6 dan 96 (tinggi) $\mathrm{mg} / \mathrm{kg} /$ berat badan bagi tartrazin, 3.85 dan $38.56 \mathrm{mg} / \mathrm{kg} /$ berat badan bagi curcumin. Keputusan menunjukkan bahawa pelaksanaan oral tartrazin telah meningkat secara signifikan total tahap oksidan, arilestras, glutation reduktase dan MDA manakala terdapat penurunan yang signifikan total tahap oksidan, katalase, glutation peroksidase dalam plasma dan najis selepas 30 dan 45 hari. Vitamin E dan C telah menurun dalam plasma. Najis menunjukkan tahap vitamin A yang tinggi. Dos tartrazin yang tinggi yang menyebabkan pengubahan dalam tapak prob reaktif aldehid (ARP) DNA menunjukkan kerosakan DNA. Selepas 45 hari, kenaikan yang signifikan telah dikesan dalam tahap AST dalam kumpulan terawat rendah dan tinggi kurkumin. Manakala, elevasi arilestras telah kelihatan dalam kumpulan tinggi kurkumin selepas 45 hari. Dos tinggi kurkumin secara signifikan $(P \leq 0.05)$ telah menurunkan kepekatan vitamin C selepas 45 hari rawatan dan meningkatkan tahap vitamin E dalam plasma kumpulan kawalan selepas 30 dan 45 hari rawatan. Kajian ini menunjukkan bahawa ADI dan dos sehingga 10 kali lebih tinggi daripada ADI menunjukkan kesan negatifke atas tahap antioksidan dan ia memaparkan kepentingan untuk menggunakan dos pewarna makanan yang sesuai seperti tartrazin dan kurkumin dalam produk makanan diproses yang berbeza.

Kata kunci: Arilesteras; glutation; pewarna makanan; pemperoksidaan lipid; ROS 


\section{INTRODUCTION}

Recent argument and critique about the safety of food colorants have been coordinated towards the synthetic colorants. The natural colorants have been relatively free of disapproval may be due to the conviction that most are inferred from food sources that have been expended for numerous years (Francis 1995).

The application of natural food colorants are limited and they have a impediments compared with the synthetic colorants, in spite of the fact that they are moderately secure in terms of toxicological check and contradiction responses (Abd El-Galeel 2002). However, after using for a long time, many of them are toxic even on admissible dose and causes health complications such as; hormonal disturbance, oxidative stress production and DNA damage (Ashida et al. 2000).

In developing countries, food colorants were used, above from the ADI during various occasions which would cause severe health complications and human health hazards (Rao et al. 2006). The effect of DNA-damaging (mutagenic) of tartrazine has been reported based on animal studies (Sasaki et al. 2002). ROS can be generated from the tartrazine metabolite and accelerate the oxidative stress (Bansal et al. 2005). At high doses, it leads to the modification of liver and kidney biochemical profiles and becomes risk as it forms free radicals and induces oxidative stress on tissue (Himri et al. 2011). In order to protect against tissue or cellular damage mediated from free radicals, antioxidant is required therefore, to prevent damage to immune cells (Mourad \& Noor 2011).

Oxidative stress can also be viewed as an imbalance between the oxidants and antioxidants in the body (Rahal et al. 2014). Endogenous formation of ROS and free radicals occur due to aerobic metabolism (Sahu 2002). Free radical generation is an important characteristic of normal function of cells (Khadija et al. 2009).

Tartrazine (FD and C Yellow No. 5) is a yellow orangecolored azo dye widely used in food products, drugs, and cosmetics. This color has a potential toxicological risk (Mehedi et al. 2009). These food colorants might induced DNA damage in the gastrointestinal organs (Sasaki et al. 2002). Tartrazine is transformed into aromatic amine sulfanilic acid after being metabolized by the gastrointestinal microflora and the formed aromatic amines can generate ROS by interaction of these amino groups with nitrite or nitrate-containing foods or in the stomach, leading to organ injuries (Bansal et al. 2005; Moutinho et al. 2007). Interestingly, there are studies that indicated tartrazine to be a potential inducing agent for oxidative stress by disturbing antioxidant and prooxidant balance and forming ROS in rat brain and liver (Amin et al. 2010; El-Wahab \& Moram 2013).

On the other hand, curcumin is yellow odorless powder and used as natural food colorants. It has antiinflammatory, antifungal, antimicrobial, virucidal, antimutagenic and antioxidant properties (Rajesh et al. 2013). Literature is full of studies regarding the beneficial effect of cucumin, but there is few publications provided evidence that curcumin induced DNA damage in human lymphocytes and gastric mucosa cells in vitro (Blasiak et al. 1999). Another publication by Antunes et al. (1999) substantiates this finding in that curcumin was found to induce DNA-damage in CHO cells at a concentration of $10 \mu \mathrm{M}$. Whereas oral administration of curcumin in its low and high doses (15.75 and $157.5 \mathrm{mg} / \mathrm{kg}$ bw) for 2 months decreased hepatic lipid peroxide concentration in male albino rats.

Glutathione (GSH) is the most abundant antioxidant in all aerobic cells, presenting with high-concentrations in body fluids and tissue. GSH using enzymatic reduction, removes most of the free radicals whereas the removal of hydrogen peroxides requires catalysis of enzymes (Owen \& Butterfield 2010). During this process GSH becomes oxidized glutathione (GSSG). The nicotinamide adenine dinucleotide phosphate (NADPH)-dependent catalysis of the flavoenzyme GSH reductase effectively decreased to GSH (Aquilano et al. 2014). Aryl esterase, also known as paraoxonase (PON1), is a high-density lipoprotein (HDL) linked enzyme which hydrolyzes phenyl acetate to phenol and acetate. It is a calcium-dependent esterase. PON1's natural physiological function happens to be toxic oxidized lipids metabolism of both low-density lipoprotein (LDL) particles and HDL particles (Durrington et al. 2001). Studies have showed PON1's ability to protect against atherosclerosis by hydrolyzing particular derivatives of oxidized cholesterol and/or phospholipids in atherosclerotic lesions and in oxidized low density lipoprotein. It may also be a major modulator of risk of cardiovascular disease (Bergmeier \& Siekmeier 2004).

The enzymatic mechanism of antioxidants includes enzymes, such as glutathione peroxidase, SOD and catalase involved enzymes in recycling glutathione reductase (Halliwell 1992). Vitamin A, C, E, $\beta$ - carotene, and melatonin have vital part in protecting against induced oxidative stress in various models of experiments (Kharwar \& Haldar 2012).

Food colorants are commonly used in packed food and confectionaries to gave attractive look and these food colorants might produced several health problems in human. Low and high dose of tartrazine and curcumin 
might trigger the formation of reactive oxygen species, thereby ultimately playing a role in the development of various health issues. Significant investigation of the current study is that it has been experimented among adult animals which was not focused in previous studies.

As mentioned by Borzelleca and Hallagan (1988) that a serious draw - back of food colors studies conducted on animal studies is that infant animals are likely to be more susceptible to toxic or carcinogenic effects than older animals. Several studies are available regarding the adverse effect of different food colorants in children, male, and infant animals. Previous studies lacking the data related to antioxidants vitamins and ROS in females plasma with reference to consumption of food colorants. No previous study has evaluated the effect of different doses of tartrazine and curcumin on fecal total oxidant, total antioxidant level and antioxidants vitamins in adult female rats. Keeping in view of these aforementioned information, this study has been designed to examine the oxidative effects of curcumin and tartrazine (popular food colorants), on adult female albino rats by measuring oxidative stress parameters, including glutathione, malondialdehyde, glutathione peroxidase activity, catalase activity, arylesterase, antioxidants vitamins (A, $\mathrm{C}$ and $\mathrm{E}$ ) and DNA damage.

\section{MATERIALS AND Methods}

\section{FOOD COLORANTS USED IN THE EXPERIMENT TARTRAZINE}

Tartrazine $\left(\mathrm{C}_{16} \mathrm{H}_{9} \mathrm{~N}_{4} \mathrm{Na}_{3} \mathrm{O}_{9} \mathrm{~S}_{2}\right.$, Trisodium5-hydroxy-1-(4sulfonatophenyl)-4-(E)-(4- sulfonatophenyl) diazenyl$1 \mathrm{H}$-pyrazole-3-carboxylate, $\mathrm{MW}=534.3 \mathrm{~g} / \mathrm{mol}$, CAS $1934-21-0$, powder with purity of $86.7 \%$ ) is synthetic food colorant and was purchased from Sigma Aldrich (Germany).

\section{CURCUMIN}

Curcumin $\left(\mathrm{C}_{21} \mathrm{H}_{20} \mathrm{O}_{6}, 1,7\right.$-bis (4-hydroxy-3methoxyphenyl)1E,6E-heptadiene-3,5-dione, $\mathrm{MW}=368.4 \mathrm{~g} / \mathrm{mol}$, CAS $458-37-7$, powder with purity of $95 \%$ ) is commercially available natural food colorant and was purchased from Carbosynth (Campton, United Kingdom).

\section{CALCULATION OF DOSE}

The animal equivalent dose (AED) can be calculated on the basis of body surface area by either dividing or multiplying the human dose $(\mathrm{mg} / \mathrm{kg})$ by the $\mathrm{Km}$ ratio provided by literature (Anroop \& Jacobin 2016; FDA
2005). AED is calculated using (1):

$$
\mathrm{AED}=\mathrm{HED} \times \mathrm{K}_{\mathrm{m}(1)}
$$

where AED is animal equivalent dose $(\mathrm{mg} / \mathrm{kg})$; HED is human dose for tartrazine and curcumin, which is 7.5 and $3 \mathrm{mg} / \mathrm{kg}$ body weight/day, respectively; and $\mathrm{K}_{\mathrm{m}}$ is body weight $(\mathrm{kg}) /$ body surface area $\left(\mathrm{m}^{2}\right)$.

$\mathrm{K}_{\mathrm{m}}$ ratio for rat used in this study is 6.2 or 0.162 (either dividing human dose with $6.2 \mathrm{~K}_{\mathrm{m}}$ ratio or multiplying the human dose by $0.162(\mathrm{mg} / \mathrm{kg}) \mathrm{K}_{\mathrm{m}}$ ratio, result dose will be same (FDA 2005)). The animals grouping and dose is mentioned in Figure 1.

\section{ANIMALS ETHICS}

The animal ethic of this study was approved by the Institute of Pharmacy, Physiology and Pharmacology, University of Agriculture, Faisalabad Ethics Committee (Punjab, Pakistan) application number 1502, dated: 04/07/17.

\section{SELECTION OF ANIMALS}

Ninety (n-90) non pregnant female Sprague Dawley rats, 6 - 7 months old (From animal house of University of Agriculture Faisalabad, Pakistan) were selected and housed in stainless steel cages individually at normal temperature $27 \pm 5{ }^{\circ} \mathrm{C}$ and under good ventilation. Animals were fed on ad libitum standard basal diet with addition of ADI and high dose of food colorants daily. The experimental diets were prepared according to Kim et al. (2005). Each group consist of six rats, categoriezed by two level of dosage i.e. low and high dose as mentioned in Figure 1. The average rat weight at the start of the trial was $200.65 \pm 15.20$.

\section{SAMPLING}

Sampling was done at 15,30 , and 45 days for control and treated groups (Control= C: C15, C30, C45, Low Tartrazine $=$ LT: LT15, LT30, LT45, High Tartrazine $=$ HT: HT15, HT30, HT45, Low Curcumin= LC: LC15, LC30, LC45, High Curcumin= HC: HC15, HC30, HC45) to check acute, sub-acute and post-acute toxicity. At the completion of each trial periods, $4-5 \mathrm{~mL}$ blood samples were collected through cardiac puncture of the rats by using $23 \mathrm{G}$ needle under general anaesthesia. Blood was collected in BD Vacutainer ${ }^{\circledR}$ heparin tubes. Then, rats were immediately euthanized through cervical dislocation. The blood was centrifuged using centrifugation (LYC; 
Centrifuge $80-2$, Jiangsu, China) for $15 \mathrm{~min}$ at $1795 \times \mathrm{g}$ and room temperature to collect plasma, which was transferred to the Eppendorf tubes and stored at $-20{ }^{\circ} \mathrm{C}$ until further analysis (within 4 weeks).

At the end of each experimental period, fresh fecal samples were collected immediately after defecation over a period of 3 days; a subsample of approximately $2 \mathrm{~g}$ was mixed with $10-\mathrm{mL}$ phosphate-buffered saline (PBS) using an electric mixer. The resulting mix was centrifuged at $3420 \times \mathrm{g}$ for $10 \mathrm{~min}$ to obtain a supernatant free of solid cellular debris. This supernatant was kept until further analysis at $-80^{\circ} \mathrm{C}$ to avoid any major deviation of composition and biological variation during long term storage (Clauss et al. 2008).

\section{DETERMINATION OF REACTIVE OXYGEN SPECIES IN PLASMA AND FECAL}

Total Antioxidants (TAC; mmol trolox Equiv./L) were determined by the applied calorimetric method was (Erel 2004). Measured the absorbance of the sample before mixing of reagent 1 and reagent 2 into sample, this will be sample blank solution. Mixed $5 \mu \mathrm{L}$ of plasma, 200 $\mu \mathrm{L}$ of Reagent 1 (Dissolved $2.46 \mathrm{~g}$ of $\mathrm{CH}_{3} \mathrm{COONa}$ in 1 $\mathrm{L}$ of deionized water. Dilute glacial acetic acid (1.705 $\mathrm{mL}$ ) into $1000 \mathrm{~mL}$ of deionized distilled water. $75 \mathrm{~mL}$ of dodium acetate solution mixed $925 \mathrm{~mL}$ of acetic acid solution by using $\mathrm{pH}$ meter. The $\mathrm{pH}$ of acetic acid solution is 3.6. Then, $278 \mu \mathrm{L}$ of $\mathrm{H}_{2} \mathrm{O}_{2}$ solution $(35 \%)$ was diluted to $1000 \mathrm{~mL}$ with buffer solution. Then, 0.549 $\mathrm{g}$ of ABTS was dissolved in $100 \mathrm{~mL}$ of prepared solution (final concentration: $10 \mathrm{mmol} / \mathrm{L}$ ). Incubate it for one hour at room temperature. The color of ABTS -1 appeared. The colored reagent was stable for at least 6 months at $4{ }^{\circ} \mathrm{C}$ ) and $20 \mu \mathrm{L}$ of reagent 2 (Dissolved $32.8 \mathrm{~g}$ of $\mathrm{CH}_{3} \mathrm{COONa}$ in $1000 \mathrm{~mL}$ of deionized water. Dilute reagent glacial acetic acid to $1000 \mathrm{~mL}$ with deionized water. About 940 $\mathrm{mL}$ of sodium acetate solution was mixed with $60 \mathrm{~mL}$ of acetic acid solution by using $\mathrm{pH}$ meter. The $\mathrm{pH}$ of acetic sodium acetate buffer was 5.8. Stable the buffer for at least 6 months at $4{ }^{\circ} \mathrm{C}$. Then, after mixing incubate the assay solution for five min and measured the absorbance at $660 \mathrm{~nm}$. Reduction in absorbance is directly proportional to the concentration of antioxidants. Determination of catalase Activity (KU/L) was done by following the procedure of Goth (1991). Standard curve was plotted to conclude the results of catalase level in plasma and fecal. Glutathione Reductase (GR; U/mL) was determined by adopting the method of Bergmeyer (1965). Measured the absorbance at $340 \mathrm{~nm}$. The GR activity will be calculated by (2):

$\mathrm{U} / \mathrm{mL}=\Delta \mathrm{A} 340 \mathrm{~nm} / \mathrm{min} \times 3 \times \mathrm{Df} /(6.22)(0.1)$

Determination of Glutathione Peroxidase (GPX; U/L) was done by the protocol of Alam et al. (2013). Calculated the resulted by comparing with standard curve. GPx activity was measured at $340 \mathrm{~nm}$. For the determination of Total Oxidants (TOS; $\mu$ mol $\mathrm{H}_{2} \mathrm{O}_{2}$ Equiv./L), colorimetric method was used (Erel 2005). Mixed $225 \mu \mathrm{L}$ of reagent 1 ((Xylenol orange $(150 \mu \mathrm{M})$, $\mathrm{NaCl}(140 \mathrm{mM})$, Glycerol (1.35M), pH1.75)) with $35 \mu \mathrm{L}$ of the sample. After mixing measured first absorbance at biochromatic length (560 and $800 \mathrm{~nm}$ ). Then, mixed $11 \mu \mathrm{L}$ of reagent 2 (Ferrous ammonium sulfate $5 \mathrm{mM}$, O-dianisidine dihydrochloride $10 \mathrm{mM}$ ) with the solution containing reagent 1 and the sample. Then, measured the final absorbance after 4 min of reagent 2 mixing. Measured the absorbance from serial dilution to draw a standard curve between absorbance and concentration of hydrogen peroxide. Then, measured the absorbance at main wavelength $560 \mathrm{~nm}$ and at secondary wavelength $800 \mathrm{~nm}$ (Bichromatic). Used the delta change in the absorbance to calculate the actual concentrations (Final Absorbance First Absorbance $=\Delta$ Absorbance) from the standard curve of hydrogen peroxide in terms of micromolar hydrogen peroxide equivalent per liter $\left(\mu \mathrm{M} \mathrm{H}_{2} \mathrm{O}_{2}\right.$ Equiv/L). The arylesterase's activity of enzymes was evaluated through spectrophotometric by using (Biosystem, BTS-330) using the process of Juretic et al. (2006). Arylestrase activity was measured using substrate, phenylacetate. $0.1 \mathrm{~mL}$ of diluted plasma was taken from 200 times diluted serum in 0.1 mol L-1 Tris-HCL buffer (pH8.0) in eppendorfs and $2.7 \mathrm{~mL}$ buffer was added and mixed well. Then, $20 \mathrm{mmol}$ L-1 phenylacetate was added and after incubation of $5 \mathrm{~min}$ take reading as $\mathrm{R} 2$ at $270 \mathrm{~nm}$ at $37^{\circ} \mathrm{C}$ on spectrophotometer by following the increase of phenol concentration. The arylestrase activity was calculated by following formula and was expressed in international units can be refer in (3). An international unit is amount of hydrolyzed substrate in $\mu \mathrm{mol}$ per min.

$$
\text { Arylesterase activity }\left(\frac{\mathrm{U}}{\mathrm{L}}\right)=\frac{\text { Absorbance } / 5}{0.017} \times 200
$$

Lipid peroxidation was evidenced by measuring the formation of malondialdehyde (MDA) using the method of Tüközkan et al. (2006). About $0.5 \mathrm{~mL}$ of plasma was centrifuged at $1795 \times \mathrm{g}$ for 10 min with $2.5 \mathrm{~mL}$ of $20 \%$ trichloroacetic acid (TCA) in a $10 \mathrm{~mL}$ centrifuge 
tube. Then, $1 \mathrm{~mL}$ of $0.67 \%$ thiobarbituric acid (TBA) was added to the mixture and warmed for thirty min in a boiling water bath followed by rapid cooling. Then, it was added into a $4 \mathrm{~mL}$ of n-butyl alcohol followed by centrifugation at $1795 \times \mathrm{g}$ for $15 \mathrm{~min}$ and organic layer separated and malondialdehyde (MDA) content in the plasma was determined from the absorbance at $532 \mathrm{~nm}$ by spectrophotometer against butanol. The standard of 20 $\mathrm{nmol} / \mathrm{mL}$ tetraethoxypropane (TEP) was used. The results were expressed as $\mathrm{nmol} / \mathrm{mL}$ plasma.

\section{ANTIOXIDANT VITAMINS IN PLASMA AND FECAL DETERMINATION OF VITAMIN A}

Vitamin A was determined by the method of Rutkowski et al. (2006). One $\mathrm{mL}$ of the sample was taken into the test-tube I (centrifugal) with a tight stopper and added $1 \mathrm{~mL}$ of the $\mathrm{KOH}$ solution, plugged the tube and shake vigorously for $1 \mathrm{~min}$ - heat the tube in a water bath $(60$ ${ }^{\circ} \mathrm{C}, 20 \mathrm{~min}$ ), then, cool it down in cold water. Added $1 \mathrm{~mL}$ of xylene, plug the tube and shake vigorously again for 1 min. Centrifuged the tube $(1500 \times \mathrm{g}, 10 \mathrm{~min})$, collected the whole of the separated extract (upper layer) and transfer it to the test tube II made of 'soft' (sodium) glass measured the absorbance $\mathrm{A}$ of the obtained extract at $335 \mathrm{~nm}$ against xylene. Irradiated the extract in the test tube II to the UV light for $30 \mathrm{~min}$, then measured the absorbance A2 calculated the concentration $\mathrm{c} 1$ of vitamin $\mathrm{A}(\mu \mathrm{M})$ in the analyzed liquid, using (4):

$$
C x=(A 1-A 2) \times 22.23
$$

where 22.23 is multiplier received on basis of the absorption coefficient of $1 \%$ solution of vitamin A (as the retinol form) in xylene at $335 \mathrm{~nm}$ in a measuring cuvette about thickness $=1 \mathrm{~cm}$. xylene $(\mathrm{a} / \mathrm{a}) ; 1 \mathrm{M}$ solution of potassium hydroxide in $90 \%$ ethanol.

\section{DETERMINATION OF VITAMIN C}

Determination of vitamin $\mathrm{C}$ was carried out by adopting the method of Rutkowski and Grzegorczyk (1998). One mL of sample was measured into the centrifugal test-tube, added 1 $\mathrm{mL}$ of the phosphotungstate reagent (PR), thoroughly mixed and left in a room temperature for $30 \mathrm{~min}$. Centrifuged the tube $(7000 \times \mathrm{g}, 10 \mathrm{~min})$, and collected the whole of the separated supernatant with a pipette the supernatant is a test sample for spectrophotometric measurements. Standard sample was prepared as mentioned (using $1 \mathrm{~mL}$ of the standard solution instead of the analysed liquid), without centrifugation. Measured the absorbance of the test sample Ax and of the standard sample A at $700 \mathrm{~nm}$ against the mixture PR: $50 \mathrm{mM}$ solution of oxalic acid = $1: 1(\mathrm{v} / \mathrm{v})$ as a reference sample of vitamin $\mathrm{C}(\mu \mathrm{M})$. The concentration $\mathrm{Cx}$ of vitamin $\mathrm{C}(\mu \mathrm{M})$ in the analysed liquid sample, using (5).

$$
C x=\left(A_{x} / A_{s}\right) \times C_{s}
$$

where $\mathrm{C}_{\mathrm{x}}$ is the concentration of the sample solution; $\mathrm{C}_{\mathrm{s}}$ is the concentration of the standard solution; $A_{x}$ is the absorbance of test sample; and $\mathrm{A}_{\mathrm{s}}$ is the absorbance of standard sample.

Phosphotungstate reagent (PR), prepared periodically, as it's used up (suspension of $150 \mathrm{~g}$ sodium tungstate molybdenium-free and $60 \mathrm{~g}$ sodium hydrogen phosphate anhydrous in $240 \mathrm{~mL}$ DI water, mixed with heating to dissolve and slowly added $145 \mathrm{~mL} 3.7 \mathrm{M}$ Sulphuric acid (VI); Solution was heated for $2 \mathrm{~h}$ with reflux condenser not allowing it to boiling; after cooling the solution down, $\mathrm{pH}$ was adjusted to 1.0 by adding dropwise concentrated sulphuric acid (VI); the reagent should be light greenishyellow, a darker one is useless); $56.8 \mu \mathrm{M}$ vitamin $\mathrm{C}$ (L-ascorbic acid) standard solution made with use $50 \mathrm{mM}$ solution of oxalic acid as a solvent.

\section{DETERMINATION OF VITAMIN E}

Vitamin E was determined by using the method of Rutkowski et al. (2005). About $0.5 \mathrm{~mL}$ of the sample was measured into the test-tube I (centrifugal) with a tight stopper. $0.5 \mathrm{~mL}$ of anhydrous ethanol was added and shake vigorously the plugged test tube for $1 \mathrm{~min}$. Added $3 \mathrm{~mL}$ xylene, plugged the test tube and shake vigorously for another $1 \mathrm{~min}$. Centrifuged the tube to separate the extract $(1500 \times \mathrm{g}, 10 \mathrm{~min})$; simultaneously measure 0.25 $\mathrm{mL}$ solution of batophenanthroline into a usual test-tube II. $1.5 \mathrm{~mL}$ of the extract (upper layer) was collected and transferred to the test-tube II and mix the content. About $0.25 \mathrm{~mL}$ of $\mathrm{FeCl}_{3}$ solution was added into the test tube II, mixed it. Added $0.25 \mathrm{~mL}$ of $\mathrm{H}_{3} \mathrm{PO}_{4}$ solution and mix again; this way a test sample is obtained for spectrophotometric measurements. Then, prepared the standard sample $(0.5 \mathrm{~mL}$ of the standard solution instead of the analysed liquid):using Trolox; prepare as the test sample, using a-tocopherol; add $0.5 \mathrm{~mL}$ of DI water instead of anhydrous ethanol at the beginning of the analysis; do not centrifuge this sample - measured the absorbance of the test sample Ax and of the standard sample A at $539 \mathrm{~nm}$ against the blank test (preparation; as the test sample but using water instead of the analysed liquid) of vitamin $\mathrm{E}$ $(\mu \mathrm{M})$ in the analysed liquid, using the a/a formula. 
Anhydrous ethanol; xylene (mixture of isomers); $6.02 \mathrm{mM}$ solution of batophenanthroline (stable for three weeks in a fridge), $0.98 \mathrm{mM}$ solution of anhydrous iron chloride (III) (stable for one week in a fridge) and 40 $\mathrm{mM}$ solution of crystalline orthophosphoric acid - all in anhydrous ethanol; $23.2 \mu \mathrm{M}$ standard solution of vitamin E (as substance Trolox - in DI water, or as a-tocopherol - in anhydrous ethanol).

Dietary antioxidant compounds are normally poorly digested and absorbed in the small intestine, and then enters the colon (Bianchi et al. 2010). Hence, the present experiment was performed with the prime intention of studying whether the curcumin and tartrazine modifies digestion of antioxidants vitamins and unabsorbed dietary antioxidants reaches the colon or not. For determination of antioxidants vitamin, A, C and $\mathrm{E}$ in fecal, same methods were used as plasma.

\section{DNA DAMAGE}

DNA was extracted from blood sample of tartrazine and curcumin control and treated groups by using the extraction kit (Catalog \#:10503027, DNAzol ${ }^{\mathrm{TM}}$ Reagent; Thermo Fisher Scientific, USA). DNA damage was quantified by quantification colorimetric kit (Catalog \#K253-25; BioVision Incorporated, 155 S. Milpitas Boulevard, Milpitas, CA 95035 USA).

\section{STATISTICAL ANALYSIS}

The statistical analysis was done by using SPSS software (version, 25). The data were analysed using one-way analysis of variance (ANOVA) followed by Tukey-Kramer (TK) multiple comparisons post-test. Mean values were separated at $\mathrm{p} \leq 0.05$. The data are reported in tables as mean \pm standard deviation (SD).

\section{RESULTS}

\section{REACTIVE OXYGEN SPECIES (ROS) IN PLASMA AND FECAL}

Oral administration of curcumin and tartrazine significantly increased the total oxidants level in HT in treatment groups of 30 days. Whereas, significantly decreased the total antioxidants level in HT 45 treatment (Table 1). Catalase was significantly decreased in LC15 but increased in LC30 and LC45 compared to control, HC30 and HC45. Current findings showed that glutathione reductase was lower in LT30, HT30, HC30,
LT45, and HT45 while significantly increased in LC45 and HC45 compared to control. Whereas, elevation of arylestrase was seen in treated group of HT15, LT45, HT45 and HC45 compared to control shown in Table 1. Oral administration of low curcumin significantly decreased the MDA level in LC30 and LC45 treated groups, respectively.

This study finds out that, alterations were seen in the fecal of treated rats with high and low dose of curcumin and tartrazine. Tartrazine and curcumin administration was significantly $(p \leq 0.05)$ decreased the total antioxidants level in HT30, HC30 and HC45. Level of catalase was high in all treated groups of 15 days, LT, LC and $\mathrm{HC}$ groups of 30 days; HT, LC an HC of 45 days compared to control (Table 2). Whereas, glutathione reductase was significantly $(\mathrm{p} \leq 0.05)$ decreased in HT15, LC15, LT30, LC30 and increased in HT30, LC30, LT45, LC45 and HC45 compared to control mentioned in Table 2. Regarding arylestrase, curcumin treated group (LC30) showed significant $(\mathrm{p} \leq 0.05)$ increased level whereas low and high tartrazine treated group depicted higher level arylesterase after 45 days. MDA level was significantly low in LT15, LC15 and HC15 compared to control.

\section{ANTIOXIDANTS VITAMINS IN PLASMA AND FECAL}

The present study showed that low and high doses of curcumin and tartrazine significantly $(\mathrm{p} \leq 0.05)$ decreased the concentration of vitamin $\mathrm{C}$ in all groups of 30 days, HT45 and HC45. Concentration of vitamin $\mathrm{C}$ have been lower in low and high doses of curcumin and tartrazine group of 15 days compared to control. Oral administration of tartrazine and curcumin significantly $(p \leq 0.05)$ increased the level of vitamin E in HT30, HC30, LT45 and HC45 (Table 3).

Oral administration of tartrazine significantly increases the level of vitamin A in fecal of HT45 and HC45. Vitamin C was significantly high in fecal after 45 days of treatment with high curcumin dose as compared to control. Regarding vitamin E, it was significant increment in HT30, HC30, LT45 and HC45 as compared to control group (Table 3).

\section{DNA DAMAGE}

Current finding showed that oral administration of curcumin and tartrazine did not caused alteration in the ARP sites of DNA showing the DNA damage in treated group compared to control after 30 and 45 days of treatment as mentioned in Table 4. 
TABLE 1. Effects of tartrazine and curcumin on reactive oxygen species in plasma after 15, 30 and 45 days of treatment

\begin{tabular}{|c|c|c|c|c|c|c|c|c|}
\hline Days & $\begin{array}{l}\text { Food color } \\
\text { exposure }\end{array}$ & $\operatorname{TOS}(\mu \mathrm{mol} / \mathrm{l})$ & $\begin{array}{c}\text { TAS } \\
(\mathrm{mmol} / \mathrm{l})\end{array}$ & CAT (KU/L) & GP (U/L) & GSH (U/mL) & $\mathrm{ARY}(\mathrm{U} / \mathrm{L})$ & $\begin{array}{c}\text { MDA (nMol/ } \\
\mathrm{mL})\end{array}$ \\
\hline \multirow{5}{*}{15} & Control & $17.86 \pm 2.38^{\mathrm{de}}$ & $5.01 \pm 0.69^{\mathrm{ab}}$ & $19.46 \pm 6.3^{\mathrm{de}}$ & $50.49 \pm 5.80^{\text {abcde }}$ & $413.49 \pm 49.64^{\mathrm{ab}}$ & $39.13 \pm 0.62^{b}$ & $0.84 \pm 0.12^{\mathrm{c}}$ \\
\hline & LT & $18.76 \pm 3.07$ de & $4.11 \pm 0.65^{\mathrm{ab}}$ & $14.66 \pm 2.83^{\mathrm{de}}$ & $29.52 \pm 20.73 \mathrm{de}$ & $373.73 \pm 91.99$ abcd & $38.89 \pm 0.18^{b}$ & $1.16 \pm 0.44^{\mathrm{abc}}$ \\
\hline & HT & $19.09 \pm 3.27$ de & $3.93 \pm 0.56^{\mathrm{ab}}$ & $25.48 \pm 6.37$ bcde & $22.26 \pm 9.24^{\mathrm{e}}$ & $365.63 \pm 79.18$ abcd & $47.72 \pm 5.61^{\mathrm{a}}$ & $0.66 \pm 0.26^{\mathrm{abc}}$ \\
\hline & LC & $16.38 \pm 3.82^{\mathrm{e}}$ & $4.29 \pm 0.83^{\mathrm{ab}}$ & $11.84 \pm 2^{\mathrm{e}}$ & $45.82 \pm 16.61$ abcde & $392.38 \pm 42.78 \mathrm{abc}$ & $39.51 \pm 0.93^{\mathrm{b}}$ & $0.89 \pm 0.06^{\mathrm{abc}}$ \\
\hline & $\mathrm{HC}$ & $18.09 \pm 1.77$ de & $4.15 \pm 0.56^{\mathrm{ab}}$ & $19.14 \pm 5.63^{\mathrm{de}}$ & $43.27 \pm 8.32^{\text {bcde }}$ & $331.98 \pm 51.86^{\mathrm{bcd}}$ & $38.95 \pm 0.55^{\mathrm{alb}}$ & $1.19 \pm 0.85^{\mathrm{abc}}$ \\
\hline \multirow{5}{*}{30} & Control & $18.48 \pm 3.69^{\text {de }}$ & $5.1 \pm 1.77^{\mathrm{ab}}$ & $20.08 \pm 1.78^{\text {cde }}$ & $62.74 \pm 4.00^{\text {abc }}$ & $330.08 \pm 15.88$ bcd & $39.308 \pm 0.53^{\mathrm{alb}}$ & $1.07 \pm 0.29 \mathrm{abc}$ \\
\hline & LT & $38.91 \pm 13.07 \mathrm{abcd}$ & $3.70 \pm 1.05^{\mathrm{ab}}$ & $17.28 \pm 6.80^{\mathrm{de}}$ & $68.84 \pm 12.24^{\mathrm{ab}}$ & $229.65 \pm 49.67^{\mathrm{cde}}$ & $49.39 \pm 0.75^{\mathrm{a}}$ & $1.15 \pm 0.35^{\mathrm{abc}}$ \\
\hline & HT & $59.08 \pm 27.61^{\mathrm{a}}$ & $3.47 \pm 0.59^{\mathrm{b}}$ & $15.98 \pm 2.5^{\text {de }}$ & $46.11 \pm 7.067^{\text {abcde }}$ & $239.03 \pm 64.17^{\text {cde }}$ & $45.15 \pm 4.07^{\mathrm{ab}}$ & $1.82 \pm 0.05^{\mathrm{abc}}$ \\
\hline & LC & $23.12 \pm 1.68^{\text {cde }}$ & $4.99 \pm 0.58^{\mathrm{ab}}$ & $39.72 \pm 18.66^{\mathrm{ab}}$ & $64.45 \pm 22.81^{\mathrm{abc}}$ & $413.53 \pm 43.04 \mathrm{ab}$ & $38.93 \pm 0.34^{\mathrm{b}}$ & $0.75 \pm 0.12^{\mathrm{c}}$ \\
\hline & $\mathrm{HC}$ & $27.34 \pm 10.04^{\mathrm{cde}}$ & $4.78 \pm 0.78^{a b}$ & $27.72 \pm 7.19^{\text {bcd }}$ & $49.45 \pm 28.62$ abcde & $211.90 \pm 142.78^{\mathrm{de}}$ & $44.58 \pm 7.52^{\mathrm{ab}}$ & $1.28 \pm 0.42^{\mathrm{abc}}$ \\
\hline \multirow{5}{*}{45} & Control & $36.02 \pm 13.23$ bcde & $6.04 \pm 1.28^{\mathrm{a}}$ & $34.08 \pm 6.76^{\mathrm{abc}}$ & $55.78 \pm 10.92 \mathrm{abcd}$ & $243.83 \pm 38.37$ bcde & $39.01 \pm 0.45^{\mathrm{b}}$ & $1.36 \pm 0.39^{\mathrm{abc}}$ \\
\hline & LT & $48.19 \pm 10.77^{\mathrm{ab}}$ & $4.15 \pm 0.75^{\mathrm{ab}}$ & $23.45 \pm 8.08^{\text {cde }}$ & $39.21 \pm 4.89$ bcde & $101.83 \pm 31.52^{\mathrm{e}}$ & $49.85 \pm 6.14^{\mathrm{a}}$ & $2.02 \pm 0.66^{\mathrm{ab}}$ \\
\hline & HT & $52.53 \pm 19.72^{\mathrm{ab}}$ & $3.30 \pm 0.47^{b}$ & $22.97 \pm 3.710^{\text {cde }}$ & $37.47 \pm 5.75^{\text {cde }}$ & $153.23 \pm 35.35^{\mathrm{e}}$ & $51.47 \pm 5.25^{\mathrm{a}}$ & $2.05 \pm 0.61^{\mathrm{ab}}$ \\
\hline & $\mathrm{LC}$ & $40.05 \pm 9.93$ abcd & $4.82 \pm 0.90^{\mathrm{ab}}$ & $45.08 \pm 4.86^{\mathrm{a}}$ & $73.87 \pm 28.00^{\mathrm{a}}$ & $520.88 \pm 81.10^{\mathrm{a}}$ & $39.64 \pm 0.79^{\mathrm{b}}$ & $0.85 \pm 0.14^{c}$ \\
\hline & $\mathrm{HC}$ & $42.36 \pm 6.38^{\mathrm{abc}}$ & $5.06 \pm 3.11^{\mathrm{ab}}$ & $27.55 \pm 3.81^{\mathrm{bcd}}$ & $49.28 \pm 7.41^{\text {bcde }}$ & $531.46 \pm 24.51^{\mathrm{a}}$ & $47.71 \pm 7.49^{\mathrm{a}}$ & $2.15 \pm 1.52^{\mathrm{a}}$ \\
\hline
\end{tabular}

Values shown are mean $( \pm \mathrm{SD})$ from $\mathrm{n}=6 \mathrm{rats} /$ group at each timepoint. Values in each column followed by different letters are significantly different ( $\mathrm{p} \leq 0.05$ ). $\mathrm{C}=$ Control, $\mathrm{LT}=$ Low Tartrazine, $\mathrm{HT}=$ High Tartrazine, $\mathrm{LC}=$ Low Curcumin, HC= High Curcumin at 15, 30 and 45, TOS= Total oxidants status; TAS $=$ Total Antioxidants Status; $\mathrm{CAT}=$ Catalase $; \mathrm{GP}=$ Glutathione peroxidase; $\mathrm{GSH}=$ Glutathione; $\mathrm{ARY}=$ Arylesterase $\mathrm{MDA}=$ Malondialdehyde

TABLE 2. Effects of tartrazine and curcumin on reactive oxygen species in fecal after 15,30 and 45 days of treatment

\begin{tabular}{|c|c|c|c|c|c|c|c|c|}
\hline Days & $\begin{array}{c}\text { Food color } \\
\text { exposure }\end{array}$ & $\operatorname{TOS}(\mu \mathrm{mol} / 1)$ & TAS $(\mathrm{mmol} / \mathrm{l})$ & CAT $(\mathrm{KU} / \mathrm{L})$ & GP (U/L) & GR (U/mL) & ARY (U/L) & $\begin{array}{c}\text { MDA (nMol/ } \\
\mathrm{mL})\end{array}$ \\
\hline \multirow{5}{*}{15} & Control & $16.08 \pm 3.49^{\circ}$ & $3.18 \pm 0.22 \mathrm{abc}$ & $77.51 \pm 3.01 \mathrm{de}$ & $304.18 \pm 3.66^{\mathrm{abc}}$ & $558.60 \pm 3.29^{\mathrm{bc}}$ & $44.27 \pm 0.77^{\mathrm{c}}$ & $0.87 \pm 0.06^{\mathrm{ab}}$ \\
\hline & LT & $17.06 \pm 4.70^{\mathrm{c}}$ & $2.37 \pm 0.34^{\mathrm{abc}}$ & $176.14 \pm 66.81^{\mathrm{abc}}$ & $196.42 \pm 4.77^{\mathrm{abc}}$ & $592.95 \pm 4.07^{\mathrm{b}}$ & $44.90 \pm 0.77^{\mathrm{c}}$ & $0.64 \pm 0.10^{\mathrm{b}}$ \\
\hline & HT & $15.26 \pm 3.20^{\mathrm{c}}$ & $2.26 \pm 0.59^{\mathrm{bc}}$ & $213.18 \pm 12.99^{\mathrm{ab}}$ & $160.41 \pm 6.61^{\mathrm{c}}$ & $478.95 \pm 25.21^{\mathrm{de}}$ & $46.22 \pm 0.36^{\mathrm{c}}$ & $1.35 \pm 0.52^{\mathrm{a}}$ \\
\hline & LC & $16.45 \pm 0.88^{\mathrm{c}}$ & $2.43 \pm 0.42^{\mathrm{abc}}$ & $180.22 \pm 11.11^{\mathrm{abc}}$ & $170.62 \pm 0.81^{\mathrm{bc}}$ & $383.10 \pm 40.18^{\mathrm{f}}$ & $45.18 \pm 0.83^{\mathrm{c}}$ & $0.64 \pm 0.09^{\mathrm{b}}$ \\
\hline & $\mathrm{HC}$ & $16.48 \pm 0.78^{\mathrm{c}}$ & $2.49 \pm 0.39^{\mathrm{abc}}$ & $164.58 \pm 5.00^{\text {bc }}$ & $270.71 \pm 0.59^{\mathrm{abc}}$ & $548.80 \pm 50.23^{\text {bcd }}$ & $43.13 \pm 0.61^{\mathrm{c}}$ & $0.65 \pm 0.11^{\mathrm{b}}$ \\
\hline \multirow{5}{*}{30} & Control & $19.44 \pm 6.01^{\mathrm{bc}}$ & $3.98 \pm 1.18^{\mathrm{ab}}$ & $230.90 \pm 1.90^{\mathrm{a}}$ & $386.57 \pm 3.86^{\mathrm{abc}}$ & $596.72 \pm 5.38^{\mathrm{b}}$ & $46.93 \pm 6.36^{c}$ & $0.67 \pm 0.13^{\mathrm{b}}$ \\
\hline & LT & $39.83 \pm 7.07^{a b c}$ & $2.01 \pm 0.50^{\mathrm{bc}}$ & $132.23 \pm 3.35^{\mathrm{cd}}$ & $486.23 \pm 12.34^{\mathrm{a}}$ & $211.99 \pm 1.71^{\mathrm{g}}$ & $44.40 \pm 1.83^{\mathrm{c}}$ & $0.52 \pm 0.05^{\mathrm{b}}$ \\
\hline & HT & $38.74 \pm 13.71^{a b c}$ & $1.69 \pm 0.45^{\mathrm{c}}$ & $222.03 \pm 7.58^{\mathrm{a}}$ & $177.44 \pm 3.48^{\mathrm{bc}}$ & $683.05 \pm 2.85^{\mathrm{a}}$ & $46.48 \pm 2.35^{\mathrm{c}}$ & $0.69 \pm 0.20^{\mathrm{b}}$ \\
\hline & LC & $46.94 \pm 18.93^{\mathrm{a}}$ & $2.65 \pm 0.43^{\mathrm{abc}}$ & $88.79 \pm 7.35^{\text {de }}$ & $255.49 \pm 5.94 \mathrm{abc}$ & $511.91 \pm 2.74^{\mathrm{cde}}$ & $59.72 \pm 1.27^{\mathrm{a}}$ & $0.60 \pm 0.15^{\mathrm{b}}$ \\
\hline & $\mathrm{HC}$ & $44.61 \pm 13.16^{\mathrm{ab}}$ & $2.14 \pm 0.56^{\mathrm{bc}}$ & $75.85 \pm 3.14^{\mathrm{e}}$ & $149.18 \pm 1.43^{\mathrm{c}}$ & $594.48 \pm 4.23^{b}$ & $42.00 \pm 1.30^{\mathrm{c}}$ & $0.55 \pm 0.06^{\mathrm{b}}$ \\
\hline \multirow{5}{*}{45} & Control & $30.97 \pm 13.82^{\mathrm{abc}}$ & $4.27 \pm 0.43^{\mathrm{a}}$ & $180.24 \pm 1.72^{\mathrm{abc}}$ & $486.18 \pm 85.64^{\mathrm{a}}$ & $592.14 \pm 4.23^{\mathrm{b}}$ & $42.43 \pm 2.65^{\mathrm{c}}$ & $0.61 \pm 0.11^{\mathrm{b}}$ \\
\hline & LT & $41.84 \pm 8.99^{a b c}$ & $2.31 \pm 0.26^{\mathrm{abc}}$ & $180.96 \pm 2.36^{\mathrm{abc}}$ & $242.70 \pm 59.30^{\mathrm{abc}}$ & $702.92 \pm 15.20^{\mathrm{a}}$ & $45.55 \pm 2.28^{\mathrm{b}}$ & $0.59 \pm 0.07^{\mathrm{b}}$ \\
\hline & HT & $50.19 \pm 1.15^{\mathrm{a}}$ & $2.67 \pm 1.59^{\mathrm{abc}}$ & $50.96 \pm 8.96^{\mathrm{e}}$ & $321.74 \pm 67.07 \mathrm{abc}$ & $707.94 \pm 2.61^{\mathrm{a}}$ & $46.44 \pm 2.02^{\mathrm{b}}$ & $0.56 \pm 0.06^{\mathrm{b}}$ \\
\hline & LC & $47.35 \pm 4.28^{\mathrm{a}}$ & $2.64 \pm 0.49^{\mathrm{abc}}$ & $44.16 \pm 1.47^{\mathrm{el}}$ & $242.64 \pm 67.54^{\mathrm{abc}}$ & $455.04 \pm 6.83^{e f}$ & $42.56 \pm 0.80^{\mathrm{c}}$ & $0.58 \pm 0.08^{b}$ \\
\hline & $\mathrm{HC}$ & $55.24 \pm 5.68^{\mathrm{a}}$ & $2.27 \pm 0.51^{\mathrm{bc}}$ & $37.20 \pm 0.99^{\mathrm{e}}$ & $466.26 \pm 68.88^{\mathrm{ab}}$ & $597.17 \pm 63.07^{\mathrm{b}}$ & $42.02 \pm 0.06^{\mathrm{c}}$ & $0.62 \pm 0.10^{\mathrm{b}}$ \\
\hline
\end{tabular}

Values shown are mean $( \pm \mathrm{SD})$ from $\mathrm{n}=6 \mathrm{rats} /$ group at each timepoint. Values in each column followed by different letters are significantly different ( $\mathrm{p} \leq 0.05$ ). $\mathrm{TOS}=$ Total oxidants status; $\mathrm{TAS}=$ Total Antioxidants Status; $\mathrm{CAT}=$ Catalase; $\mathrm{GP}=$ Glutathione peroxidase $\mathrm{GSH}=\mathrm{Glutathione} ; \mathrm{ARY}=\mathrm{Aylesterase} ; \mathrm{MDA}=\mathrm{Malondialdehyde}$ 
TABLE 3. Effects of tartrazine and curcumin antioxidants vitamin in plasma and fecal samples after 15, 30 and 45 days of treatment

\begin{tabular}{|c|c|c|c|c|c|c|c|}
\hline \multirow[b]{2}{*}{ Days } & \multirow{2}{*}{$\begin{array}{l}\text { Food color } \\
\text { exposure }\end{array}$} & \multicolumn{3}{|c|}{ Plasma } & \multicolumn{3}{|c|}{ Fecal } \\
\hline & & $\begin{array}{c}\text { Vitamin A } \\
(\mu \mathrm{M} / \mathrm{L})\end{array}$ & Vitamin $\mathrm{C}(\mu \mathrm{M} / \mathrm{L})$ & Vitamin $\mathrm{E}(\mu \mathrm{M} / \mathrm{L})$ & $\begin{array}{c}\text { Vitamin A } \\
(\mu \mathrm{M} / \mathrm{L})\end{array}$ & $\begin{array}{c}\text { Vitamin } C \\
(\mu \mathrm{M} / \mathrm{L})\end{array}$ & $\begin{array}{l}\text { Vitamin E } \\
(\mu \mathrm{M} / \mathrm{L})\end{array}$ \\
\hline \multirow{5}{*}{15} & Control & $4.518 \pm 2.08^{a}$ & $15.29 \pm 4.14^{\mathrm{abc}}$ & $16.55 \pm 3.34^{\mathrm{a}}$ & $3.05 \pm 0.65^{\mathrm{bc}}$ & $9.30 \pm 1.19^{\mathrm{ab}}$ & $2.53 \pm 0.66^{\mathrm{c}}$ \\
\hline & LT & $3.851 \pm 1.34^{\mathrm{a}}$ & $11.64 \pm 4.88^{\text {bcdef }}$ & $14.57 \pm 3.70^{\mathrm{abc}}$ & $3.88 \pm 1.79^{a b c}$ & $8.76 \pm 0.32^{b}$ & $2.21 \pm 0.96^{\mathrm{c}}$ \\
\hline & HT & $2.456 \pm 1.27^{\mathrm{a}}$ & $11.51 \pm 4.16^{\text {bcdef }}$ & $10.00 \pm 2.62^{\mathrm{bcd}}$ & $4.96 \pm 0.65^{\mathrm{abc}}$ & $9.77 \pm 2.28^{\mathrm{ab}}$ & $2.54 \pm 1.20^{\mathrm{c}}$ \\
\hline & $\mathrm{LC}$ & $3.458 \pm 1.12^{\mathrm{a}}$ & $14.22 \pm 1.50^{\mathrm{abcd}}$ & $16.47 \pm 4.77^{\mathrm{a}}$ & $2.92 \pm 0.44^{\mathrm{c}}$ & $9.13 \pm 0.76^{\mathrm{ab}}$ & $2.33 \pm 0.96^{\mathrm{c}}$ \\
\hline & $\mathrm{HC}$ & $3.28 \pm 1.46^{\mathrm{a}}$ & $12.74 \pm 3.45^{\text {abcde }}$ & $8.44 \pm 1.34^{\text {de }}$ & $3.16 \pm 1.78^{b c}$ & $9.3 \pm 1.95^{\mathrm{ab}}$ & $2.18 \pm 0.85^{c}$ \\
\hline \multirow{5}{*}{30} & Control & $3.85 \pm 1.96^{\mathrm{a}}$ & $18.67 \pm 2.49^{\mathrm{a}}$ & $14.79 \pm 2.21^{\mathrm{ab}}$ & $2.97 \pm 1.23^{\mathrm{bc}}$ & $7.71 \pm 1.59^{\mathrm{b}}$ & $2.22 \pm 0.96^{\mathrm{c}}$ \\
\hline & LT & $2.681 \pm 0.70^{\mathrm{a}}$ & $9.09 \pm 0.34^{\text {cdef }}$ & $9.67 \pm 2.05^{\mathrm{bcd}}$ & $4.22 \pm 0.30^{\mathrm{abc}}$ & $9.12 \pm 0.99^{\mathrm{ab}}$ & $3.18 \pm 0.93^{b c}$ \\
\hline & HT & $2.631 \pm 1.89^{\mathrm{a}}$ & $6.11 \pm 1.69^{f}$ & $9.39 \pm 2.70^{\mathrm{cd}}$ & $5.60 \pm 1.00^{\mathrm{abc}}$ & $9.24 \pm 1.20^{\mathrm{ab}}$ & $5.07 \pm 0.41^{\mathrm{ab}}$ \\
\hline & $\mathrm{LC}$ & $3.494 \pm 3.06^{\mathrm{a}}$ & $11.63 \pm 4.95^{\text {bcdef }}$ & $13.53 \pm 1.83^{\mathrm{abcd}}$ & $3.96 \pm 0.68^{a b c}$ & $6.99 \pm 0.32^{b}$ & $1.97 \pm 0.32^{\mathrm{c}}$ \\
\hline & $\mathrm{HC}$ & $2.841 \pm 0.79^{\mathrm{a}}$ & $8.05 \pm 2.18^{\mathrm{def}}$ & $11.54 \pm 2.03^{\mathrm{abcd}}$ & $5.75 \pm 0.17^{\mathrm{ab}}$ & $8.88 \pm 0.87^{b}$ & $5.7 \pm 0.03^{\mathrm{a}}$ \\
\hline \multirow{5}{*}{45} & Control & $4.23 \pm 1.25^{\mathrm{a}}$ & $17.03 \pm 2.74^{\mathrm{ab}}$ & $11.47 \pm 2.91 \mathrm{abcd}$ & $3.29 \pm 0.17^{b c}$ & $8.56 \pm 1.29^{b}$ & $3.31 \pm 0.88^{b c}$ \\
\hline & LT & $5.13 \pm 1.78^{a}$ & $11.09 \pm 4.26^{\text {bcdef }}$ & $3.85 \pm 2.62^{\mathrm{ef}}$ & $4.98 \pm 0.63^{a b c}$ & $10.16 \pm 0.65^{a b}$ & $5.69 \pm 0.36^{\mathrm{a}}$ \\
\hline & HT & $2.68 \pm 2.70^{a}$ & $8.06 \pm 1.79 \mathrm{def}$ & $1.03 \pm 0.88^{\mathrm{f}}$ & $6.17 \pm 1.14^{\mathrm{a}}$ & $10.38 \pm 0.06^{\mathrm{ab}}$ & $1.35 \pm 0.82^{\mathrm{c}}$ \\
\hline & LC & $3.43 \pm 0.88^{\mathrm{a}}$ & $13.29 \pm 2.31$ abcde & $2.30 \pm 1.39^{\mathrm{f}}$ & $5.03 \pm 0.68 \mathrm{abc}$ & $9.45 \pm 0.54^{\mathrm{ab}}$ & $2.28 \pm 0.96^{\mathrm{c}}$ \\
\hline & $\mathrm{HC}$ & $2.24 \pm 1.99^{\mathrm{a}}$ & $7.42 \pm 1.85^{\text {ef }}$ & $0.82 \pm 0.31^{\mathrm{f}}$ & $6.28 \pm 0.51^{\mathrm{a}}$ & $12.87 \pm 2.23^{\mathrm{a}}$ & $5.82 \pm 0.35^{\mathrm{a}}$ \\
\hline
\end{tabular}

Values shown are mean $( \pm \mathrm{SD})$ from $\mathrm{n}=6$ rats/group at each timepoint. Values in each column followed by different letters are significantly different ( $\leq \leq 0.05$ )

TABLE 4. Effects of tartrazine and curcumin on ARP Site of DNA for DNA damage

\begin{tabular}{ccc}
\hline Days & Food color exposure & DNA damage \\
\hline & Control & $8.99 \pm 4.15^{\mathrm{a}}$ \\
LT & HT & $5.29 \pm 2.68^{\mathrm{a}}$ \\
& LC & $5.66 \pm 1.44^{\mathrm{a}}$ \\
& HC & $8.74 \pm 6.54^{\mathrm{a}}$ \\
& Control & $8.49 \pm 3.08^{\mathrm{a}}$ \\
& LT & $4.35 \pm 1.71^{\mathrm{a}}$ \\
& HT & $8.65 \pm 2.07^{\mathrm{a}}$ \\
& LC & $19.39 \pm 15.9^{\mathrm{a}}$ \\
& HC & $5.96 \pm 2.59^{\mathrm{a}}$ \\
& & $8.08 \pm 1.89^{\mathrm{a}}$ \\
\hline
\end{tabular}

Values shown are mean $( \pm \mathrm{SD})$ from $\mathrm{n}=6 \mathrm{rats} /$ group at each timepoint. Values in each column followed by different letters are significantly different $(\mathrm{p} \leq 0.05)$. 


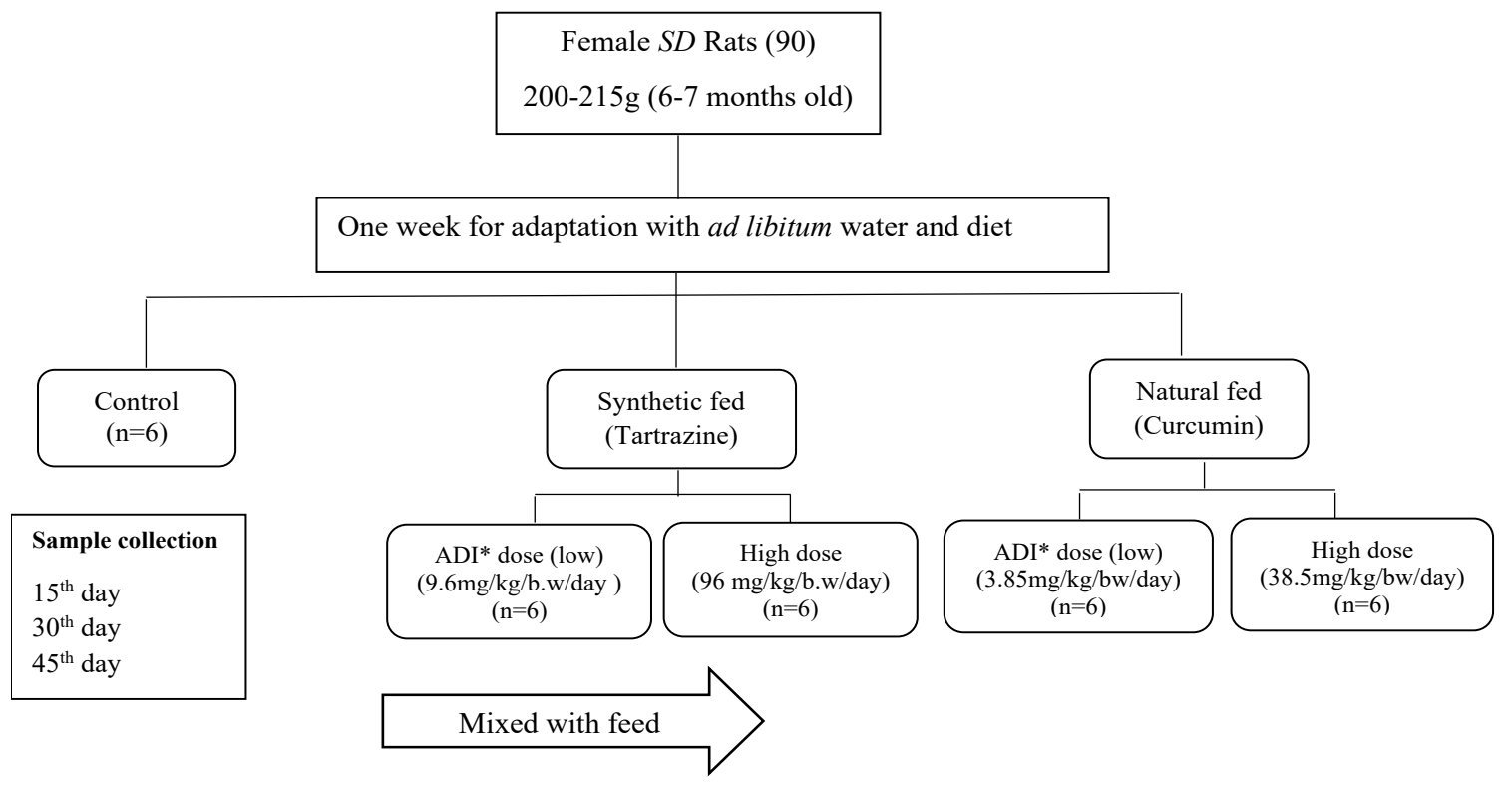

*ADI= Acceptable daily intake

FIGURE 1. Experimental animals and study protocol

\section{DISCUSSION}

Results are in agreement with Amin et al. (2010) who check the effect of tartrazine and carmoisine synthetic food colorants: El-Wahab and Moram (2013) who found reduction in antioxidant level and high level of oxidants/ reactive oxygen species (ROS) after administration of brilliant blue, carmoisine, and tartrazine in male rats. Whereas, curcumin did not affect total oxidant and total antioxidants level of treated group after 15, 30, and 45 days, but in previous studies curcumin was found to have a strong antioxidant effect (Amani et al. 2010). A decrease in the production of antioxidants, mechanism of antioxidants and accelerated production of ROS are some of the reasons behind the occurrence of oxidative stress (Rahal et al. 2013). In this study, the reduction of total antioxidant level in the plasma of tartrazine-treated animals may be associated to enhanced generation of free radical generation because of administering tartrazine and/or impairing machinery of antioxidant resulting in enhanced oxidative stress.

Pincemail et al. (2002) stated that production of ROS is accurately regulated because the antioxidants have the appropriate capacity. The risk of chronic diseases from oxidative stress is decreased when antioxidants are applied because they reduce oxidation of lipid and protein by scavenging species of oxygen (Farombi et al. 2007).

These results of catalase are in line with Amin et al. (2010) who stated that high dose of tartrazine treated male rats indicated particular reduction in the level of catalase enzymes. Similar results were found by Golli et al. (2016) who resulted that oral administration of tartrazine decreased the level of catalase in liver, whereas increased in kidney tissue of treated rats. Catalase accelerates the degradation of hydrogen peroxide in water molecules and oxygen to prevent the formation of hydroxyl radicals, acting as the first line of defensive antioxidant enzyme (Kaur \& Sandhir 2006). Futhermore, Abdel-Aziz et al. (2019) also concluded that $300 \mathrm{mg} / \mathrm{kg}$ b.wt. dose of tartrazine given with orogastric tube to wister rats for 30 days significantly decreased the catalase level. Whereas, low curcumin dose after 30 day and high dose after 45 days elevated the catalase level in treated as compared to control. It is confirmed from previous studies that curcumin was found to have a strong antioxidant effect (Amani et al. 
2010). Results are different from Abdel-aziz et al. (2019) who stated that cucurmin have non-significant effect on catalase level of treated rats after 30 days.

The results of glutathione are in accordance with Amin et al. (2010) who found decreased level of GSH in tartrazine treated rats. Similar results were found by Golli et al. (2016) who conclude that $300 \mathrm{mg} / \mathrm{kg}$ b.wt. of tartrazine significantly decreased the hepatic GSH level. The subsequent reduction in hepatic GSH activity is suggestive of impaired hepatic detoxifying capacity. In a same way, El Wahab and Moram (2012) who noticed decrease in the GSH content in the blood of rats receiving tartrazine, carmosine and brilliant blue and it might be related to the increased utilization of GSH in conjugation with foreign compounds entering the body (Murray 1996; Thomas 1994).

Low and high doses of curcumin did not change the level of glutathione peroxidase. These results are in line with Sharad et al. (1999) who stated that oral administration of curcumin (15.7 and $157 \mathrm{mg} / \mathrm{kg}$ b.wt.) daily for 2 months did not affect either hepatic or renal glutathione as compared to the control group. Abdel-Aziz et al. (2019) further confirmed that curcumin have no effect on glutathione level in treated group after 30 days. Results of glutathione reductase are in accordance with Mehedi et al. (2009) who studied the toxic effects of tartrazine in mature male albino rats and observed a specific increase in glutathione reductase (GR) concentration. The data from the previous studies have shown that the administration of these tartrazine, carmosine and brilliant blue causes a significant decrease in the hepatic GSH level with a subsequent reduction in hepatic GST activity, which is suggestive of impaired hepatic detoxifying capacity (Murray 1996). One possible consequence of this event is the increased amount of the food additive reactive metabolite irreversibly bound to hepatic protein sulfur nucleophiles (Halliwell et al. 1997; Liu et al. 1999).

When a strong oxidative stress is exposed to mammalian cells, this condition may need both increased action of GSH for maintaining redox status, but also boosted the precursors and supply of energy for increasing content of GSH and pass it to the required areas. Moreover, when there is prolonged oxidative stress when the cells are not capable anymore to defend themselves from oxidative stress, the GSH/GSSG ratio will decrease as a result of reduced free GSH level (Aquilano et al. 2014). Superoxide anion, hydrogen peroxide and hydroxyl radical could enhance oxidative stress and could be formed by the nitrosamine metabolism (Bansal 2005).
Regarding the arylesterase, results are different from the Saima (2011) who concluded that tartrazine have non-significant effect on arylesterase level in treated rabbit after 15 day. Differences in results might be due to species, dose of administration of tartrazine and duration of study. The current study stated the increased malondialdehyde (MDA, end product of lipid peroxidation) levels to be causing oxidative stress in the rats treated with tartrazine. Similar results were found by Amin et al. (2010) who resulted that low and high dose of carmosine and tartrazine showed significantly increased in liver MDA level of male rats. Current results are also in line with Golli et al. (2016) who concluded that $300 \mathrm{mg} / \mathrm{kg} \mathrm{b.wt}$. dose of tartrazine increased the MDA level in liver and kidney of treated rats after 30 days. Furthermore, Abdel-Aziz et al. (2019) also concluded that $300 \mathrm{mg} / \mathrm{kg}$ b.wt. dose of tartrazine given with orogastric tube to wister rats for 30 days significantly increased the MDA level. These results are also related to the study by Demirkol et al. (2012), who examined the oxidative effects of tartrazine and other azo dyes on Chinese hamsters and concluded that tartrazine increased the MDA level in treated group. Tartrazine administration may attribute increased peroxidation of lipid which can lead to the formation of ROS.

On the other hand, high curcumin dose significantly elevated the MDA level in treated animal after 45 days. Results are different from Kalpana and Menon (2004) who found that oral administration of curcumin (15.7 or $157 \mathrm{mg} / \mathrm{kg}$ b.wt.) daily for 2 months decreased hepatic lipid peroxide concentration as compared to the control group. Another study also concluded that curcumin have no significant effect on MDA level of treated group (AbdelAziz et al. 2019).

Current study is accordance with Orozco et al. (2010) who observed a specific enhancement in production of fecal ROS by $36 \%$ after iron supplementation $(\mathrm{p}=0.026)$. Babbs (1990) and Erhardt et al. (1997) gave out hypothesis that fecal matrix can be involved in the formation of ROS and it may be important generating colorectal cancer. The generation of reactive species of $\mathrm{O}$ and $\mathrm{N}$ in the intestine are contributed by endogenously produced metabolites, intestinal microflora, and dietary factors. The demonstration to produce feces dilution to form hydroxyl radicals has been done by Babbs (1990). It is due to the catalytic activity of the available Fe and oxidative metabolism of the bacteria. Free radicals in the large bowel can be generated through minor inflammatory reactions as well. ROS is elaborated by activated macrophages and neutrophils upon migration to injured tissues which can cause cell damage through inflammation (Babior 1978). 
Furthermore, phospholipid breakdown can be induced in the membrane of colonic cells by bile acids affecting the gut oxidative status (Craven et al. 1986). Various important biological products can be damaged by free radicals, such as; lipids, proteins, and DNA. Additionally, aromatic hydroxylation is accomplished by the hydroxyl radical (Grootveld \& Halliwell 1986); this is specifically harmful in the colon where a number of harmful chemicals from foods, additives, constituents and drugs, can be easily converted into carcinogen mechanism. The production of free radical in the colon can be contributed by different dietary intakes. But pro-oxidants only contribute to oxidative stress. Oral administration of rutoside in rats, ameliorated inflammatory diseases, through preventing depletion of glutathione (Cruz et al. 1998).

Previous study discussed about the positive impact of tartrazine as iron chelators on fecal antioxidant status in regard to the assumptions; simultaneously, the antioxidant status of human feces has positive correlation with the polyphenolic-containing beverages consumption (Garsetti et al. 2000). In contrast, diets having high pellets more supplemented vitamins (Vitamin E) and iron enhanced levels of dietary vitamin $\mathrm{E}$ have positive influence on the status of fecal antioxidant (Stone et al. 2002).

Antioxidant vitamins (A, C and E) level of control and treated experimental group are presented in Table 3. Result are contrast with the Cemek et al. (2014) who did not observed any statistically significant changes in antioxidant vitamin levels in serum of rats treated with $15 \mathrm{mg} / \mathrm{kg}$ b.wt. of tartrazine. Vitamin E (mostly $\alpha$-tocopherols, lipid soluble antioxidant) and Vitamin $\mathrm{A}$ (retinol and $\beta$-carotene) can take part in the mechanism of redox of the cell and neutralize ROS (Sayed et al. 2012).

Any xenobiotic or endobiotic that produces oxidative stress by generating ROS or inhibiting antioxidant systems is called pro-oxidant. All kinds of molecules and cellular tissues that have free radicals are included in it. Literatures dealing with this subject is lacking, in this regards not been able to find a studies targeting antioxidant vitamin in plasma and fecal. It is difficult to compare results with the literature. Thus, the study is a unique work to present relationship between antioxidant vitamins and synthetic and natural food colorants. Present work is a major reference of which results certainly have great potential to be translated into important advances in public health.

Current study showed that administration of curcumin and tartrazine did not cause any significant alterations in ARP sites of DNA. Concerning the genotoxicity of synthetic colorants, results are contradicted with Himri et al. (2011) who showed that DNA damage in leucocytes was caused by tartrazine as detected by comet assay. This genotoxic effect is because of the direct contact of tartrazine with nuclear DNA. Data pertaining to the tartrazine's genotoxic effect with positive results are available. Mpountoukas et al. (2010) investigated the toxic effect of tartrazine at $0.02-8 \mathrm{mM}$ in in vitro human peripheral blood cells. Additionally, chromosomal aberrations in fibroblast cells of Muntiacus muntjac were induced by tartrazine (Chung et al. 1981). Results were opposite from Hassan (2010) who showed that regular dose of tartrazine administration ( 7.5 and $15 \mathrm{mg} / \mathrm{kg} \mathrm{b.wt}$.) for seven weeks leads to kidney and liver damage of DNA. Induction of tartrazine-induced DNA damage in comet assays was observed in cells from the colon of mice at a low dose (10 or $100 \mathrm{mg} / \mathrm{kg}$ ) (Sasaki et al. 2002) that is slightly higher than the recommended regular intake of humans approved by the Joint FAO/WHO Expert Committee on Food Additives (FAO/WHO 1999).

\section{CONCLUSION}

Based on the results mentioned before, it can be stated that tartrazine is capable to form ROS, thus, accelerate oxidative stress, changing the plasma antioxidants vitamins profiles which in turn, decrease the level of antioxidant. Curcumin, as a natural food color have minimum side effect on the total antioxidant level. From the present study it was concluded that use of food colorants in food items increases the chances of different diseases in the body i.e. free radical production leading to development of oxidative stress in the body and prone the body to other serious ill effects. Therefore, tartrazine consumption control is necessary for health and minimizing the usage of tartrazine as well as high dose of curcumin, especially in foods on daily basis, is highly advisable.

\section{ACKNOWLEDGEMENTS}

Special thanks to Mansoor Ahmad Khuhro for providing assistance in statistical analysis. The authors declare that they have no conflict of interest.

\section{REFERENCES}

Abd El-Galeel, M.A.S. 2002. Solubility and stability of natural food colorants in microemulsions. University Bonn, Ph.D. Thesis (Unpublished).

Abdel-Aziz, H.M., Alazouny, Z.M., Abdelfadeel, K.F. \& Abohashem, A.A. 2019. Effect of tartrazine on thyroid gland of male rat and ameliorating role of curcumin (histological and immunohistochemical study). Journal of Biochemistry and Cell Biology 2(111): 2.

Alam, M.N., Nusrat, J.B. \& Rafiquzzaman, M.D. 2012. Review on in vivo and in vitro methods evaluation of antioxidant activity. Saudi Pharmaceutical Journal 21: 143-152. 
Amani, A.R., Somchit, M.N., Konting, M.M. \& Kok, L. 2010. Vitamin $\mathrm{E}$ and curcumin intervention on lipid-peroxidation and antioxidant defense system. Journal of American Science 6: $52-62$

Amin, K., Hameid, H.A. \& Elsttar, A.A. 2010. Effect of food azo dyes tartrazine and carmoisine on biochemical parameters related to renal, hepatic function and oxidative stress biomarkers in young male rats. Food and Chemical Toxicology 48(10): 2994-2999.

Antunes, L.M., Araujo, M.C., Dias, F.L. \& Takahashi, C.S. 1999. Modulatory effects of curcumin on the chromosomal damage induced by doxorubicin in Chinese hamster ovary cells. Teratogen Carcinogen Mutagen 19: 1-8.

Aquilano, K., Baldelli, S. \& Ciriollo, M.R. 2014. Glutathione: New roles in redox signaling for an old antioxidant. Front Pharmacology 5: 196.

Ashida, H., Hashimoto, T., Tsuji, S., Kanazawa, K. \& Danno, G.I. 2000. Synergistic effects of food colors on the toxicity of 3-amino-1, 4-dimethyl-5H-pyrido [4, 3-b] indole (Trp-P-1) in primary cultured rat hepatocytes. Journal of Nutritional Science and Vitaminology 46(3): 130-136.

Babbs, C.F. 1990. Free radicals and the etiology of colon cancer. Free Radical Biology and Medicine 8: 191-200.

Babior, B.M. 1978. Oxygen-dependent microbial killing by phagocytes. New England Journal of Medicine 298: 659668.

Bansal, A.K., Bansal, M., Soni, G. \& Bhatnagar, D. 2005. Modulation of N-nitrosodiethylamine (NDEA) induced oxidative stress by vitamin $\mathrm{E}$ in rat erythrocytes. Human Experimental Toxicology 24: 297-302.

Bergmeier, C., Siekmeier, R. \& Gross, W. 2004. Distribution spectrum of paraoxonase activity in HDL fractions. Clinical Chemistry 50(12): 2309-2315.

Bergmeyer, H.U. 1965. Methods of Enzyme Analysis. Cambridge: Academic Press. p. 682.

Bianchi, M.A., Francesca, S., Daniele, D.R., Silvia, V., Nicoletta, P., Laura, F., Maria, L.C., Claudia, P., Annamaria, B., Ivana, Z. \& Furio, B. 2010. Ability of a high-total antioxidant capacity diet to increase stool weight and bowel antioxidant status in human subjects. British Journal of Nutrition 104(10): 1500-1507.

Blasiak, J., Trzeciak, A., Malecka-Panas, E., Drzewoski, J., Iwanienko, T., Szumiel, I. \& Wojewodzka, M. 1999. DNA damage and repair in human lymphocytes and gastric mucosa cells exposed to chromium and curcumin. Teratogen Carcinogen Mutagen 19: 19-31.

Borzelleca, J.F. \& Hallagan, J.B. 1988. A chronic toxicity/ carcinogenicity study of FD \& C Yellow No. 5 (tartrazine) in mice. Food Chem. Toxicol. 26(3): 189-194.

Cemek, M., Büyükokuroğlu, M.E., Sertkaya, F., Alpdağtaş, S., Hazini, A., Önül, A. \& Göneş, S. 2014. Effects of food color additives on antioxidant functions and bioelement contents of liver, kidney and brain tissues in rats. Journal of Food and Nutrition Research 2(10): 686-691.

Chung, K.T. \& Fulk, G.E. 1981. Mutagenicity testing of some commonly used dyes. Applied and Environmental Microbiology 42(4): 641-648.
Clauss, M., Wittenbrink, M.M., Castell, J.C., Kienzle, E., Dierenfeld, E.S., Flach, E.J. \& Hatt, J.M. 2008. Quantification of enterobacteriaceae in faeces of captive black rhinoceros (Diceros bicornis) in relation to dietary tannin supplementation. Journal of Animal Physiology and Animal Nutrition 92(1): 29-34.

Craven, P.A., Fanstiel, J.P. \& Derubertis, F.R. 1986. Role of reactive oxygen metabolites in bile salt stimulation of colonic epithelial proliferation. Journal of Clinical Investigations 77: 850-859.

Cruz, T., Galvez, J., Ocete, M.A., Crespo, M.E., Sanchez de Medina, L.H.F. \& Zarzuelo, A. 1998. Oral administration of rutoside can ameliorate inflammatory bowel disease in rats. Life Science 62: 687-695.

Demirkol, O., Zhang, X. \& Ercal, N. 2012. Oxidative effects of tartrazine (CAS No. 1934-21-0) and new coccin (CAS No. 2611-82-7) azo dyes on CHO cells. Journal Fur Verbraucherschutz Und Lebensmittelsicherhei 7(3): 229-236.

Durrington, P.N., Bhatnagar, D., Mackness, M.I., Morgan, J., Julier, K., Khan, M.A. \& France, M. 2001. An omega-3 polyunsaturated fatty acid concentrate administered for one year decreased triglycerides in simvastatin treated patients with coronary heart disease and persisting hypertriglyceridaemia. Heart 85(5): 544-548.

El-Wahab, H.M.F.A. \& Moram, G.S.E.D. 2013. Toxic effects of some synthetic food colorants and/or flavor additives on male rats. Toxicology and Industrial Health 29(2): 224-232.

Erel, O. 2005. A new automated colorimetric method for measuring total oxidant status. Clinical Biochemistry 38: 1103-1111.

Erel, O. 2004. A novel automated method to measure total antioxidant response against potent free radical reactions. Clinical Biochemistry 37: 112-119.

Erhardt, J.G., Lim, S.S. \& Bode, J.C. 1997. A diet rich in fat and poor in dietary fiber increases the in vitro formation of reactive oxygen species in human feces. Journal of Nutrition 127: 706-709.

FAO/WHO. 1999. Evaluation of certain food additives and contaminants (Fifty-first report of the Joint FAO/WHO Expert Committee on Food Additives). WHO Technical Report Series, No. 891. Garsetti, M., Pellegrini, N., Baggio, C. \& Brighenti, F. 2000. Antioxidant capacity in human faeces. British Journal of Nutrition 84: 705-710.

Farombi, E.O., Abarikwu, S.O., Adedara, I.A. \& Oyeyemi, M.O. 2007. Curcumin and kolaviron ameliorate di-nbutylphthalate-induced testicular damage in rats. Basic Clinical Pharmacology and Toxicology 100(1): 43-48.

FDA. 2005. Guidance for Industry: Estimating the Maximum Safe Starting Dose in Adult Healthy Volunteer. Rockville, MD: US Food and Drug Administration.

Golli, E.N. 2016. Toxicity Induced after subchronic administration of the synthetic food dye tartrazine in adult rats, role of oxidative stress. Recent Advance in Biological Medicine 2: 21-28.

Goth, L. 1991. A simple method for determination of serum catalase and reversion of reference range. Clinica Chimica Acta 2(3): 143-151. 
Grootveld, M. \& Halliwell, B. 1986. Aromatic hydroxylation as a potential measure of hydroxyl radical formation in vivo. Biochemical Journal 237: 449-504.

Halliwell, B. 1992. Reactive oxygen species and the central nervous system. Journal of Neurochemistry 59: 1609-1623.

Halliwell, B., Zentella, A., Gomez, E.O. \& Kershenobich, D. 1997. Antioxidants and human disease: A general introduction. Nutrition Reviews 55(1): 44. Hassan, G. 2010. Effects of some synthetic coloring additives on DNA damage and chromosomal aberrations of rats. Arab Journal of Biotechnology 13(1): 13-24.

Himri, I., Bellahcen, S., Souna, F., Belmekki, F., Aziz, M., Bnouham, M., Zoheir, J., Berkia, Z., Mekhfi, H. \& Saalaoui, E. 2011. A 90-day oral toxicity study of Tartrazine, a synthetic food dye, in Wistarrats. International Journal of Pharmacy and Pharmacological Science 3: 159-169.

Juretic, D., Motejlkova, A., Kunovic, B., Rekic, B., Mestric, Z.F., Vujic, L., Mesic, R., Bajalo, J.L. \& Rudolf, V.S. 2006. Paraoxanase/arylesterase in serum of patients with type-II diabetes mellitus. Acta Pharmaceutical 56: 59-68.

Kalpana, C. \& Menon, V.P. 2004. Modulatory effects of Curcumin on lipid peroxidation and antioxidant status during nicotine-induced toxicity. Polish Journal of Pharmacology 56: 581-586.

Kaur, M. \& Sandhir, R. 2006. Comparative effects of acute and chronic carbofuran exposure on oxidative stress and drug-metabolizing enzymes in liver. Drug Chemistry and Toxicology 29(4): 415-421.

Khadija, A.A., Ati, S., Mohammed, A.M. \& Mohamed, H.E. 2009. Response of broiler chicks to dietary monosodium glutamate. Pakistan Veterinary Journal 29(4): 165-168.

Kharwar, R.K. \& Haldar, C. 2012. Daily variation in antioxidant enzymes and lipid peroxidation in lungs of a tropical bird Perdiculaasiatica: Role of melatonin and nuclear receptor RORa. Comparative Biochemistry and Physiology Part A. Molecular and Integrative Physiology 162: 296-302.

Kim, J.H., Hahm, D.H., Yang, D.C., Lee, H.J. \& Shim, I. 2005. Effect of crude saponin of Korean red ginseng on high-fat diet-induced obesity in the rat. Journal of Pharmacological Science 97: 124-131.

Liu, T., Chen, C., Chen, C. \& Chi, C. 1999. Safrole-induced oxidative damage in the liver of Sprague-Dawley rats. Food and Chemical Toxicology 37(7): 697-702.

Mehedi, N., Ainad-Tabet, S., Mokrane, N., Addou, S., Zaoui, C., Kheroua, O. \& Saidi, D. 2009. Reproductive toxicology of tartrazine (FD and C Yellow No. 5) in swiss albino mice. American Journal of Pharmacology and Toxicology 4(4): 130-135.

Mourad, I.M. \& Noor, N.A. 2011. Aspartame (a widely used artificial sweetener) and oxidative stress in the rat cerebral cortex. International Journal of Biomedicine Science 2(1): 4-10.

Moutinho, I.L.D., Bertges, L.C. \& Assis, R.V.C. 2007. Prolonged use of the food dye tartrazine (FD\&C yellow no 5) and its effects on the gastric mucosa of Wistar rats. Brazilian Journal of Biology 67(1): 141-145.
Mpountoukas, P., Pantazaki, A., Kostareli, E., Christodoulou, P., Kareli, D., Poliliou, S. \& Lialiaris, T. 2010. Cytogenetic evaluation and DNA interaction studies of the food colorants amaranth, erythrosine and tartrazine. Food and Chemical Toxicology 48(10): 2934-2944.

Murray, R. 1996. Metabolism of xenobiotics. In Harper's Biochemistry. Stamford: Appleton \& Lange. p. 868.

Orozco, M.N., Solomons, N.W., Schumann, K., Friel, J.K. $\&$ de Montenegro, A.L.M. 2010. Antioxidant-rich oral supplements attenuate the effects of oral iron on in situ oxidation susceptibility of human feces. Journal of Nutrition 140(6): 1105-1110.

Owen, J.B. \& Butterfield, D.A. 2010. Measurement of oxidized/reduced glutathione ratio. In Protein Misfolding and Cellular Stress in Disease and Aging: Concept, Protocols, edited by Bross, P. \& Gregersan, N. New York: Humana Press. pp. 269-277.

Pincemail, J., Bonjean, K., Cayeux, K. \& Defraigne, J.O. 2002. Me canismes physiologiques de la defense antioxydante. Nutrition and Clinical Metabolism 16: 233-239.

Rahal, A., Kumar, A., Singh, V., Yadav, B., Tiwari, R., Chakraborty, S. \& Dhama, K. 2014. Oxidative stress, prooxidants, and antioxidants: The interplay. BioMed Research International 2014. Article ID. 761264.

Rajesh, H., Rao, S.N., Megha Rani, N., Prathima, K., Shetty, R.E.P. \& Chandrashekhar, R. 2013. Phytochemical analysis of methanolic extract of Curcuma longa Linn. International Journal of Universal Pharmacy and Bio Sciences 2(2): 39-45.

Rao, P., Bhat, R.P., Sudershan, R.V. \& Krishna, T.P. 2006. Consumption of synthetic food colours during festivals in Hyderabad, India. British Food Journal 107: 276-284.

Rutkowski, M. \& Grzegorczyk, K. 1998. Kolorymetryczne oznaczanie stezenia witaminy $\mathrm{C}$ osoczu krwi przy uzyciu odczynnika fosforowolframianowego - modyfikacja metody Kyawa [Colorimetric determination of vitamin $\mathrm{C}$ concentration in blood plasma with phosphotungstate reagent- a modification of Kyaw method]. Diagnostic Laboratory 4: 243 [in Polish].

Rutkowski, M., Grzegorczyk, K. \& Paradowski, M.T. 2005. Colorimetric method of blood plasma total vitamin E determination - the own modification of Tsen method. Diagnostic Laboratory 41: 375.

Rutkowski, M., Grzegorczyk, K., Gendek, E. \& Kedziora, J. 2006. Laboratory convenient modification of Bessey method for vitamin A determination in blood plasma. Journal of Physiology and Pharmacology 57: 221.

Sahu, S.C. 2002. Dual role of organosulfur compounds in foods. Journal of Environmental Science and Health Part $C$ Environmental Carcinogen and Ecotoxicology Reviews 20(1): 61-76.

Saima, S. 2011. Effect of artificial food coloring agents on health biomarkers, antioxidant enzymes, hepatic functions, metabolic hormones and DNA damage in rabbits. University of Agriculture, M.Sc. Thesis (Unpublished).

Sasaki, Y.F., Kawaguchi, S., Kamaya, A., Ohshita, M. \& Kabasawa, K. 2002. The comet assay with 8 mouse 
organs: Results with 39 currently used food additives. Mutation Research/Genetic Toxicology and Environmental Mutagenesis 519(1-2): 103-119.

Sayed, H.M., Fouad, D., Ataya, F.S., Hassan, H. \& Fahmy, M.A. 2012. The modifying effect of selenium and vitamins A, C, and $\mathrm{E}$ on the genotoxicity induced by sunset yellow in male mice. Mutation Research 744: 145-153.

Sharad, S.S., Sanjay, A., Utpal, P., John, T., Piperb, M.K., JiZhong, C. \& Yogesh, C.A. 1991. The effect of Curcumin on glutathione-linked enzymes in K562 human leukemia cells. Toxicology Letters 1: 87-95.

Stone, W.L., Papas, A.M., LeClair, I.O., Qui, M. \& Ponder, T. 2002. The influence of dietary iron and tocopherols on oxidative stress and ras-p21 levels in the colon. Cancer Detection and Prevention 26: 78-84.

Thomas, J.A. 1994. Oxidative stress, oxidant defense and dietary constituents. In Modern Nutrition in Health and Disease, edited by Shils, M.E., Olson, J.A. \& Shike, M. Philadelphia: Lea \& Febiger. pp. 501-512.

Tüközkan, N.A., Hüsamettin, E. \& Ilgim, S. 2006. Measurement of total malondialdehyde in plasma and tissues by highperformance liquid chromatography and thiobarbituric. Firat Tip Dergis 11(2): 88-92.

Sadaf Shakoor*, Amin Ismail \& Mohd Redzwan Sabran Department of Nutrition

Faculty of Medicine and Health Sciences

Universiti Putra Malaysia

43400 UPM Serdang, Selangor Darul Ehsan

Malaysia
Sadaf Shakoor*

Sub Campus Burewala-Vehari

University of Agriculture Faisalabad

Punjab

Pakistan

Amin Ismail

Research Centre of Excellence

Nutrition and Non-Communicable Diseases (RCOE NNCD)

Faculty of Medicine and Health Sciences

Universiti Putra Malaysia

43400 UPM Serdang, Selangor Darul Ehsan

Malaysia

\section{Zia-Ur-Rahman}

Institute of Pharmacy

Pharmacology, and Physiology

University of Agriculture Faisalabad

Punjab

Pakistan

Norhafizah Mohtarrudin

Department of Pathology

Faculty of Medicine and Health Sciences

Universiti Putra Malaysia

43400 UPM Serdang, Selangor Darul Ehsan

Malaysia

*Corresponding author; email: gs45177@student.upm.edu.my

Received: 29 March 2020

Accepted: 8 October 2020 